\title{
Seasonal Variation of Zooplankton Communities and the Effects of Environmental Factors in the Seawater Near Taishan Nuclear Power Station
}

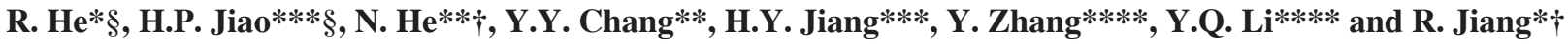 \\ *The Pearl River Hydraulic Research Institute, Guangzhou 510611, China \\ **Yichun University, Yichun 336000, China \\ ***Guangdong Province Research Center for Geoanalysis, Guangzhou 510070, China \\ ****Taishan Nuclear Power Joint Venture Co., Ltd., Jiangmen 518034, China \\ $\S$ These two authors contributed equally to this work \\ †Corresponding author: N. He; hen201236@163.com
}

Nat. Env. \& Poll. Tech.

Website: www.neptjournal.com

Received: 07-01-2021

Revised: $03-03-2021$

Accepted: 11-04-2021

Key Words:

Zooplankton

Community structure

Seasonal variations

Environment factors

Taishan nuclear power station

\section{ABSTRACT}

In the seawater near Taishan Nuclear Power Station, Zooplankton community composition and abundance, the biomass of major taxa, vertical distribution pattern, together with several environmental factors were investigated to evaluate the variation tendency as the seasons change. The structure characteristics of the zooplankton community were analyzed by Margalef species richness (d), Shannon-wiener species diversity index $\left(\mathrm{H}^{\prime}\right)$, Pielou evenness index (J'), zooplankton dominant $(\mathrm{Y})$, and dominant species replacement rate $(R)$. There are 48 species within 11 classes of zooplankton identified, including 32 species of copepods. Zooplankton species richness changed obviously in the four seasons, Spring saw the highest $\left(8010.00\right.$ ind $\left.\mathrm{m}^{-3}\right)$, followed by winter $\left(5100.00\right.$ ind $\left.\mathrm{m}^{-3}\right)$, autumn $\left(1713.75\right.$ ind $\left.\mathrm{m}^{-3}\right)$, and summer $\left(1196.25\right.$ ind $\left.\mathrm{m}^{-3}\right)$. Similar trends were observed for the wet biomass, which was highest in spring $\left(215.90 \mathrm{mg} \cdot \mathrm{m}^{-3}\right)$, followed by winter $\left(181.70 \mathrm{mg} \cdot \mathrm{m}^{-3}\right)$, summer $\left(78.56 \mathrm{mg} \cdot \mathrm{m}^{-3}\right)$, and autumn $\left(24.69 \mathrm{mg} \cdot \mathrm{m}^{-3}\right)$, which gave an annual average of $125.21 \mathrm{mg} \cdot \mathrm{m}^{-3}$. The results indicate that the abundance and biomass in spring were significantly higher than those in other seasons. Altogether 8 dominant species were identified along the whole year: Acrocalanmus gibber, Bestiolina amoyensis, Paracalanus parvus, Acartia danae, Mesocyclops leuckarti, Noctiluca scientillans, Penilla avirostris, and Lucifer penicilliger. The annual average Shannon-Wiener diversity index, Margalef diversity index, Pielou evenness index were $1.75,1.83$, and 0.74 , respectively. The effects of environmental factors on the zooplankton community were studied by $\mathrm{R}$ and canonical correspondence analysis (CCA). According to Pearson correlation analysis and canonical correspondence analysis, the most important environmental factors influencing the changes of zooplankton species composition, abundance and distribution were water temperature, salinity, and $\mathrm{pH}$ in the whole year.

\section{INTRODUCTION}

Nuclear power has played an important role in energy development. However, due to warmer waters brought by heatwaves, many nuclear facilities have already reduced their output in the recent decade. More and more people begin to pay close attention to the threat of nuclear power stations on marine life and the coastal environment, particularly after the Fukushima incident. Nuclear reactors are located near a river or the ocean since they are the most water-intensive energy-producing technology. That may bring temperature drainage, residual chlorine, radioactive materials, and other problem (Chen et al. 2017, Jiang \& Hou, 2015, Jiang \& Wang 2020, Muthulakshmi et al. 2019).

Zooplankton communities are the vital secondary producers and main drivers of the biological pump in the Marine food web (Muthulakshmi et al. 2019, Goncalves et al. 2012, Wu et al. 2011, Steinberg \& Landry 2017). Since they are highly sensitive to environmental conditions, zooplankton communities are good indicators of the coastal environment change impacts and have been widely used to study such changes and their impacts (Batchelder et al. 2013). Buesseler et al. (2016) had found that when the temperature reached $37.0^{\circ} \mathrm{C} \sim 37.6^{\circ} \mathrm{C}$, large zooplankton disappeared and Copepods dropped dramatically in the eastern Indian Ocean due to thermal drainage. Taishan Nuclear Power Station is located about $1.2 \mathrm{~km}$ to the northeast of Chixi town, Taishan city in Guangdong province.

There have been relevant studies on the zooplankton community in the coastal waters (Alagan et al. 2020, Asgari \& Steiner, 2017, Lin, et al. 2021, Maja et al. 2018, Richardson et al. 2019, Sonia et al. 2019, Thirunavukkarasu et al. 2020), however, few studies on zooplankton community 
characteristics in the waters near the nuclear power plant have been reported (Ding et al. 2019).

In this paper, four quarterly background surveys of the zooplankton community in this area from 2015 to 2016 were investigated, focusing on its community structure, abundance distribution, and seasonal changes. The relationship between the zooplankton community and several environmental factors including temperature, salinity, $\mathrm{pH}$, and nutrient salts was also discussed. Our result intended to provide fundamental information for the sustainable utilization of resources in the seawater near Taishan Nuclear Power Station.

\section{MATERIALS AND METHODS}

\section{Study Site}

The zooplankton samples were collected in the seawater near Taishan Nuclear Power Station from Dec. 2015 to Sept. 2016, including 10 points along the coast station (S1-S10) and another 10 offshore (S11-S20) (Fig. 1).

\section{Sampling}

The 20 stations were sampled quarterly from December 2015 to September 2016 for reflecting their variation in four seasons: winter (20-21, December 2015), spring (2830, March 2016), summer (25-26, June 2016), and autumn (21-23, September 2016).

At each station, water temperature, salinity, and $\mathrm{pH}$ were measured in situ with a multi-parameter water quality meter along with sample collection. For quantitative investigation, $5 \mathrm{~L}$ water samples were collected from different sampling sites by an organic glass water extractor and then filtered by a 25\# plankton net (with $20064-\mu \mathrm{m}$ apertures); And then $50 \mathrm{~mL}$ was collected in plastic bottles and immediately fixed with $5 \%$ formalin solution. The identifications were analyzed by Olympus SZ61 stereomicroscope after being settled and concentrated to $5 \mathrm{~mL}$. The phyletic analysis was conducted referring to the Chinese Marine plankton map, and Chinese phytoplankton map, and Chinese zoological freshwater copepods.

\section{Data Analysis}

The structure characteristics of the zooplankton community were analyzed by Margalef species richness $(d)$, Shannon-wiener species diversity index (H') (Shannon \& Weaver 1949), Pielou evenness index(J') (Pielou 1969), zooplankton domi$\operatorname{nant}(\mathrm{Y})$ and dominant species replacement rate $(\mathrm{R})$ (Walkusz et al. 2009, Zervoudaki et al. 2009), calculated as below:

$$
\text { Species richness index: } d=(S-1) / \log _{2}(N)
$$

( $S$ - the number of phytoplankton species, $N$ - the number of individuals of all species)

Species diversity index: $H^{\prime}=\sum\left(n_{i} / N\right) \log _{2}\left(n_{i} / N\right) \ldots(2)$ ( $n_{i}$ - the total number of individuals of the $\mathrm{i}^{\text {th }}$ species, $N$ - the total number of individuals of all species)

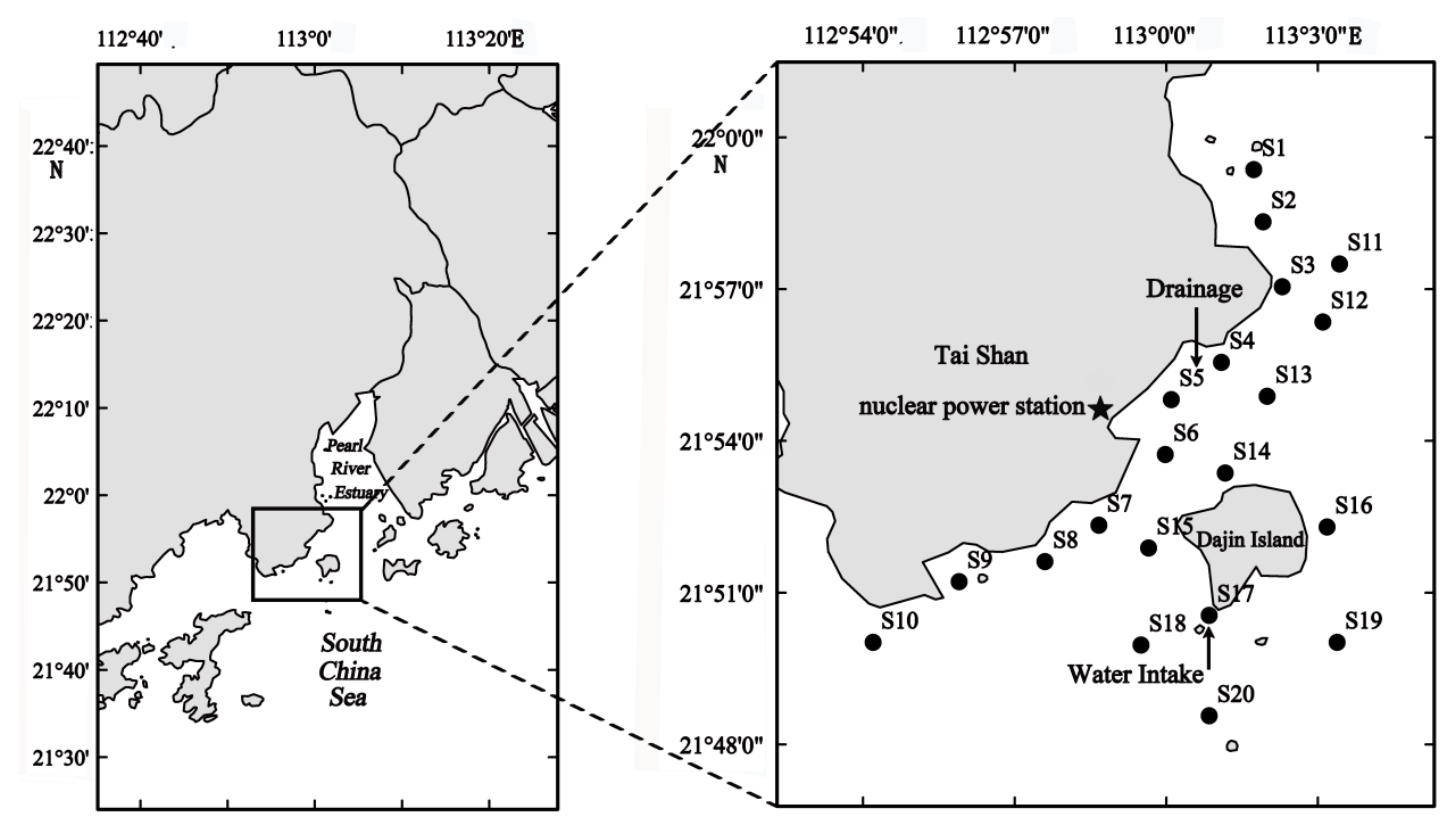

Fig. 1: Map of the different sampling stations. Intake point: Coastwise (S1-S10) and Offshore (S11-S20). 
Species evenness index: $J^{\prime}=H^{\prime} / \log 2 \mathrm{~S}$

$\left(H^{\prime}-\right.$ the diversity index, $S$ - the number of species in the sample)

Dominant index: $Y=\frac{n_{i}}{N} f_{i}, \geq 0.02$ indicates dominant species

$\left(n_{i}\right.$ - the total number of the $\mathrm{i}^{\text {th }}$ species, $f_{i}$ - the frequency of this species in each sample, $N$ - the total number of all samples)

Replacement rate of dominant species: $R=\frac{a+b-2 c}{a+b-c} \times 100 \%$

( $a, b$ - dominant species of the two adjacent periods; $c$ - the number of common dominant species.)

The R Programming Language cor and cor test functions were used for correlation analysis. The biodiversity of the zooplankton community was analyzed by large multivariate statistical software PRIMER6.0. Redundancy analysis (RDA) was performed on zooplankton species and environmental data using Canoco5.0. Canonical-correlation analysis (CCA) was conducted between six water environmental factors (water temperature, salinity, $\mathrm{pH}, \mathrm{COD}$, nitrate-nitrogen, and labile phosphate) measured at 20 stations and the abundance of 25 optimal zooplankton species.

\section{RESULTS}

\section{Species Composition}

A total of 48 species of zooplankton taxa (excluding 13 planktonic larvae) belonging to 11 taxonomic groups were identified in seawater around Taishan as shown during the seasonal surveys in Table 1. At the taxonomic level, copepods were numerically the most abundant with 32 species recorded (RA 66.67\%), followed by Sergestidae (RA $6.25 \%, 3$ species). The taxonomic groups with 2 species were Cladocera, Rotifera, and Hydromedusae, respectively. The rest classes that had only 1 species recorded were Planktonic mollusks, Cumacea, Isopoda, and Amphipoda, respectively.

The community was predominant by low salt neritic ecological groups, such as Acartia clausi, Acartia pacifica, Acartia spinicauda, Euterpina acutifrons, Labidocera sinilobata. There were also a few estuaries groups recorded (such as Sinocalanus tenellus, Schmackeria poplesia, Centropages tenuiremis), as well as salty groups (such as Paracalanus parvus, Acartiella sinensisShen, Centropages furcatus) and tropical groups (such as Acartia danae, Acrocalanmus gibber, Acartia erythraea, Lucifer intermedius) (Table 1). In terms of seasonal variation, autumn and winter saw the most complex zooplankton community with 28 species, followed by summer (19 species) and spring (15 species) successively.

\section{Zooplankton Abundance and Biomass}

In the present study, the zooplankton abundance showed a noticeable change among the study stations and between different seasons (Fig. 2). Zooplankton abundance ranged from 75.00 to 9600.00 ind. $\mathrm{m}^{-3}$ in all the samples investigated with an annual average of 4005.00 ind. $\mathrm{m}^{-3}$. The highest average abundance was observed in spring $\left(8010.00\right.$ ind. $\left./ \mathrm{m}^{3}\right)$ and followed by winter (5100.00 ind. $\left.\mathrm{m}^{-3}\right)$, autumn (1713.75 ind. $\mathrm{m}^{-3}$ ), and summer $\left(1196.25\right.$ ind. $\left.\mathrm{m}^{-3}\right)$. It presented seasonal changes as: spring $>$ winter $>$ autumn $>$ summer.

The biomass of zooplankton samples ranged from 2.63 to $815.10 \mathrm{mg} \cdot \mathrm{m}^{-3}$ with an annual average of $125.21 \mathrm{mg} \cdot \mathrm{m}^{-3}$. The total biomass of zooplankton showed similar trends with the zooplankton abundance. In general, maximum biomass occurred in spring $\left(215.90 \mathrm{mg} \cdot \mathrm{m}^{-3}\right)$, and then followed a

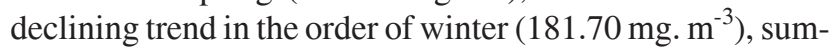
mer $\left(78.56 \mathrm{mg} \cdot \mathrm{m}^{-3}\right)$, and autumn $\left(24.69 \mathrm{mg} \cdot \mathrm{m}^{-3}\right)$, showing obvious seasonal changes (Fig. 3).

From the perspective of the horizontal distribution shown in Figs. 2-3, the abundance and biomass of zooplankton in near-shore samples collected in spring were significantly different from those in open-sea samples but similar in the other three seasons. In spring, zooplankton abundance and biomass were dramatically higher in near-shore than in opensea samples with 3.50 times and 3.22 times, respectively. The zooplankton was mainly distributed in the neritic area, while its abundance and biomass were low. This distribution pattern of zooplankton was contributed by the high abundance of Noctiluca scintillans as shown in Table 2. The zooplankton showed different distribution patterns in summer, which was mainly distributed in the estuary region to the north of the sampling station and higher compared to other stations (Fig. 2). This is because the $N$. scintillans is still dominant in the summer (Table 2). In addition, the zooplankton was mainly distributed in the southern part of the sampling area in autumn, because Penilla acirostris and Tortanus forcipatus largely appeared (Table 2) and planktonic larvae were detected at the same time. However, the abundance distribution of zooplankton was relatively uniform in winter (Fig. 2), mainly dominated by copepods (Table 2).

\section{Dominant Zooplankton Species and Their Seasonal Variations}

In the present study, 8 dominant species were found in surface seawater near Taishan during the investigation (not including 2 phytoplankton). Apparently, there were substantial seasonal changes in the zooplankton dominant species, from A. gibber, Bestiolina amoyensis, P. parvus, Acartia danae, and Mesocyclops leuckarti in winter, $N$. scintillans in spring and summer to $P$. acirostris and Lucifer penicilliger in autumn. 
Table 1: Species composition of surface zooplankton.

\begin{tabular}{|c|c|c|c|c|c|}
\hline S.No & Family/Species & Ecotype & S.No. & Family/Species & Ecotype \\
\hline \multicolumn{3}{|c|}{ Copepod } & \multicolumn{3}{|l|}{ Cladocera } \\
\hline 1 & Cyclops vicinnus & Freshwater & 36 & Ecadne tergestina & \\
\hline 2 & Pseudodiaptomus inopinus & Freshwater & 37 & Penilla acirostris & \\
\hline 3 & Acartia clausi & Nearshore low Salinity & \multicolumn{3}{|l|}{ Rotifers } \\
\hline 4 & Acartia pacifica & Nearshore low Salinity & 38 & Brachionus plicatilis & Wide-temperature- salinity group \\
\hline 5 & Acartia spinicauda & Nearshore low Salinity & 39 & Asplanchna priodonta & Freshwater group \\
\hline 6 & Paracalanus crassirostris & Nearshore low Salinity & \multicolumn{3}{|c|}{ Hydra jellyfish } \\
\hline 7 & Euterpina acutifrons & Nearshore low Salinity & 40 & Moerisia sp. & \\
\hline 8 & Microsetella norvegica & Nearshore low Salinity & 41 & Aequorea conica & \\
\hline 9 & Oithona brevicornis & Nearshore low Salinity & \multicolumn{3}{|l|}{ Protozoan } \\
\hline 10 & Oithona simplex & & 42 & Noctiluca scintillans & \\
\hline 11 & Oithona nana Giesbrecht & & \multicolumn{3}{|l|}{ Amphipoda } \\
\hline 12 & Bestiolina amoyensis & Nearshore low Salinity & 43 & Gammaridea sp. & \\
\hline 13 & Labidocera euchaeta & Nearshore low Salinity & \multicolumn{3}{|c|}{ Phytoplankton mollusks } \\
\hline 14 & Labidocera sinilobata & Nearshore low Salinity & 44 & Creseis acicula & \\
\hline 15 & Tortanus forcipatus & Nearshore low Salinity & \multicolumn{3}{|l|}{ Cumacea } \\
\hline 16 & Tortanus dextrilobatus & Nearshore low Salinity & 45 & Cumacea sp. & \\
\hline 17 & Temora turbinata & Nearshore low Salinity & \multicolumn{3}{|l|}{ Isopods } \\
\hline 18 & Acartia danae & Tropical taxa & 46 & Microniscus sp. & \\
\hline 19 & Acartia erythraea & Tropical taxa & \multicolumn{3}{|l|}{ Other } \\
\hline 20 & Acartia negligens & & \multirow[t]{2}{*}{47} & Cypridina bairdii & \\
\hline 21 & Candacia sp. & Tropical taxa & & & \\
\hline 22 & Acrocalanmus gibber & Tropical taxa & \multicolumn{3}{|c|}{ Planktonic larvae } \\
\hline 23 & Mesocyclops leuckarti & Tropical taxa & 49 & \multicolumn{2}{|l|}{ Zoea larvae (Brachyura) } \\
\hline 24 & Sinocalanus tenellus & Tropical taxa & 50 & \multicolumn{2}{|l|}{$\begin{array}{l}\text { Nauplius larvae (Cir- } \\
\text { ripedia) }\end{array}$} \\
\hline 25 & Schmackeria poplesia & Tropical taxa & 51 & \multicolumn{2}{|l|}{$\begin{array}{l}\text { Nauplius larvae (Co- } \\
\text { pepoda) }\end{array}$} \\
\hline 26 & Sinocalanus laevidactylus & Tropical taxa & 52 & \multicolumn{2}{|l|}{ Copepoda larvae } \\
\hline 27 & Centropages tenuiremis & Tropical taxa & 53 & \multicolumn{2}{|l|}{ Ophiuroidea } \\
\hline 28 & Paracalanus parvus & Wide salinity group & 54 & \multicolumn{2}{|l|}{ Ccylla serrata } \\
\hline 29 & Acartiella sinensisShen & Wide salinity group & 55 & \multicolumn{2}{|l|}{ Gastropoda larvae } \\
\hline 30 & Centropages furcatus & Wide salinity group & 56 & \multicolumn{2}{|l|}{ Mysidacea larvae } \\
\hline 31 & Pseudodiaptomus penicillus & & 57 & \multicolumn{2}{|l|}{ Polychaeta larvae } \\
\hline 32 & Canthocalanus pauper & & 58 & \multicolumn{2}{|l|}{ Macrura larvae } \\
\hline \multicolumn{2}{|c|}{ Sergestidae } & & 59 & Penaenus orientalis & \\
\hline 33 & Lucifer hanseni & & 60 & Eriocheir sinensis & \\
\hline 34 & Lucifer penicilliger & Warm water species & 61 & Eriocheir sinensis & \\
\hline 35 & Lucifer intermedius & Tropical taxa & \multicolumn{3}{|l|}{ Total $=61$} \\
\hline
\end{tabular}

To understand how the dominant species changed in different seasons, the replacement rate of the dominant species and the population turnover rate were calculated. The replacement rate of dominant species in spring-summer, summer-autumn, autumn-winter, and winter-spring was calculated as $0 \%, 100 \%, 100 \%$, and $100 \%$, respectively. Successively, the population turnover rate was $53.57 \%$, $77.27 \%, 76.79 \%$, and $67.44 \%$, respectively. Except for the same dominant species were found in spring and summer, the corresponding replacement rate was above $50 \%$. As a result, 

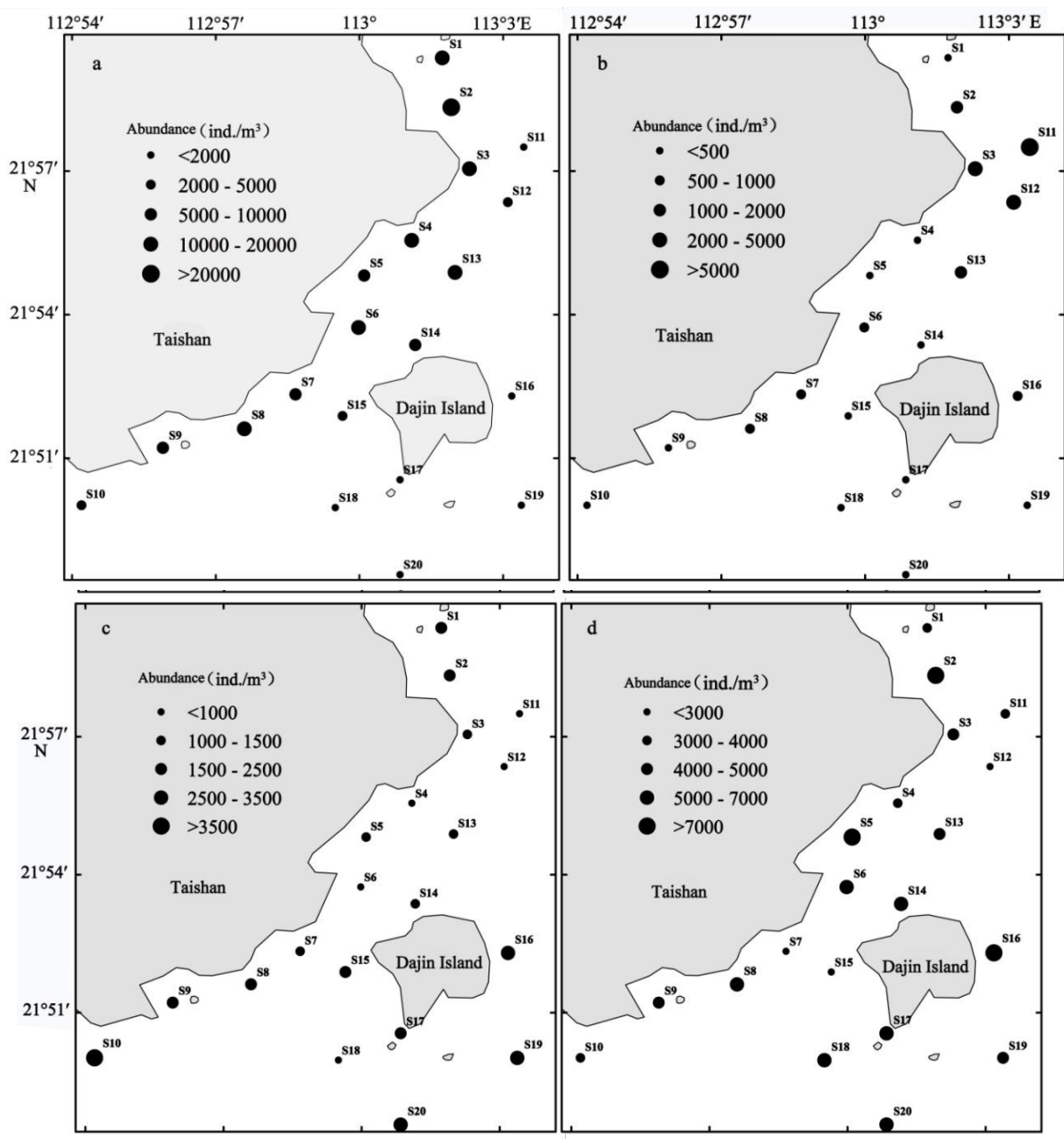

Fig. 2: Average abundance of zooplankton in different seasons (a: Spring, b: Summer, c: Autumn, d: Winter) from Dec. 2015 to Sep. 2016.

the seasonal replacement rate of zooplankton was relatively high in the whole year.

\section{Species Diversity and Seasonal Variation}

As shown in Table 3, the abundance index such as Pielou's index $(d)$, the diversity index $\left(H^{\prime}\right)$, and the Evenness index $\left(J^{\prime}\right)$ during investigation time across seasons exhibited a common trend. Pielou's index (d) was in the range of $0.2-3.1$, with an annual average of 1.75 . The diversity index ( $\left.\mathrm{H}^{\prime}\right)$ was in the range of $0.00 \sim 3.28$, with an annual average of 1.83 . The Evenness index $\left(\mathrm{J}^{\prime}\right)$ was in the range of $0.09 \sim 1.00$, with an annual average of 0.74 . The zooplankton diversity index over the 4 seasons in 20152016 was the lowest in spring and followed an increasing trend till winter. While at other times, these values were lower due to the explosive growth of some dominant species.

\section{Effects of Environmental Factors}

Environmental factors play important roles in the seasonal succession of the zooplankton community. As showed in Table 4, the results of correlation analysis were performed to evaluate the influence of environmental factors (water temperature, salinity, $\mathrm{pH}, \mathrm{COD}$, nitrate-nitrogen, and labile phosphate) on the zooplankton community (species, abundance, biomass, and diversity index). The population and abundance of zooplankton were found to be positively correlated with salinity and $\mathrm{pH}$, while negatively correlated with COD. Zooplankton biomass was positively correlated with nitrate-nitrogen and labile phosphate, while negatively correlated with water temperature. The diversity index of zooplankton was positively correlated with water temperature, salinity, and $\mathrm{pH}$, while negatively correlated with COD and nitrate-nitrogen. 

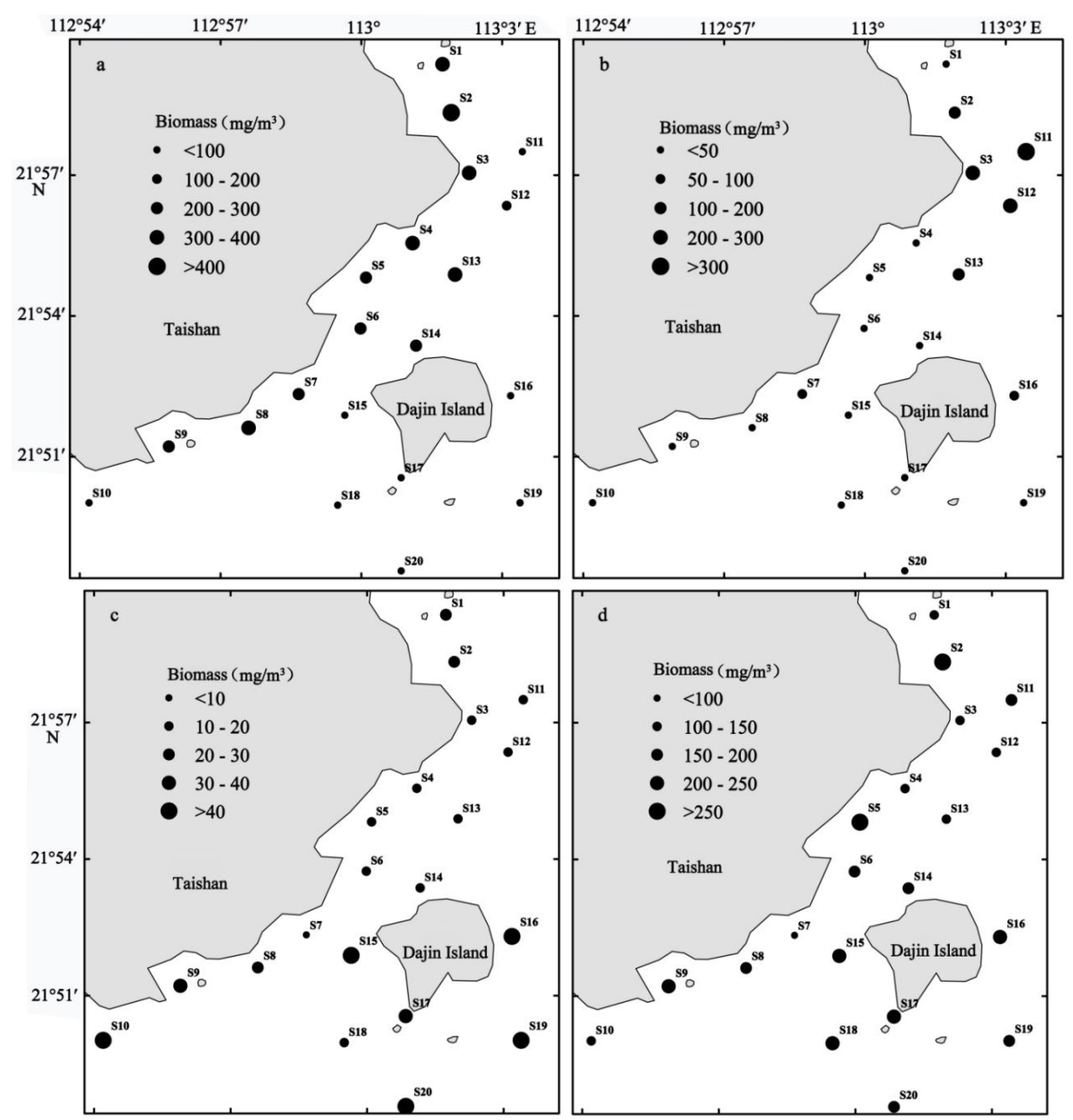

Fig. 3: Horizontal distribution of average biomass of zooplankton in different seasons (a: Spring, b: Summer, c: Autumn, d: Winter) from Dec. 2015 to Sep. 2016.

Table 2: Dominant species of zooplankton.

\begin{tabular}{|c|c|c|c|c|c|c|c|c|c|c|c|c|c|c|c|c|c|}
\hline \multirow[t]{2}{*}{ No. } & \multirow[t]{2}{*}{ Dominants } & \multicolumn{4}{|c|}{ Spring } & \multicolumn{4}{|c|}{ Summer } & \multicolumn{4}{|c|}{ Autumn } & \multicolumn{4}{|c|}{ Winter } \\
\hline & & $f \%$ & $A$ & $A \%$ & Y & $f \%$ & $A$ & $A \%$ & $Y$ & $f \%$ & $A$ & $A \%$ & Y & $f \%$ & $A$ & $A \%$ & $Y$ \\
\hline 1 & Acrocalanmus gibber & * & * & * & * & * & * & * & * & 5.0 & 18.75 & 1.22 & - & 13.00 & 780 & 15.29 & 0.13 \\
\hline 2 & Bestiolina amoyensis & * & * & * & * & * & * & * & * & * & * & * & * & 5.29 & 450 & 5.56 & 0.05 \\
\hline 3 & Paracalanus parvus & * & * & * & * & 5.0 & 7.5 & 0.63 & - & 15 & 18.75 & 1.22 & - & 16.41 & 930 & 11.48 & 0.16 \\
\hline 4 & Acartia danae & 5.0 & 3.75 & 0.05 & - & 10 & 18.8 & 1.57 & - & 40 & 56.25 & 3.67 & 0.01 & 2.65 & 300 & 3.70 & 0.03 \\
\hline 5 & Mesocyclops leuckarti & * & * & * & * & * & * & * & * & * & * & * & * & 2.12 & 270 & 3.33 & 0.02 \\
\hline 6 & Noctiluca scintillans & 90 & 7642.5 & 95.41 & 0.86 & 100 & 915 & 76.49 & 0.76 & 10 & 11.25 & 0.73 & - & * & * & * & * \\
\hline 7 & Penilla acirostris & * & * & * & * & * & * & * & * & 55 & 247.5 & 16.14 & 0.09 & * & * & * & * \\
\hline 8 & Lucifer penicilliger & * & * & * & * & * & * & * & * & 75 & 165 & 10.76 & 0.08 & * & * & * & * \\
\hline
\end{tabular}

$f \%$ - frequency of occurrence; $A$ - abundance (ind. $\left.\mathrm{m}^{3}\right) ; A \%$ - abundance percentage; $Y$ - dominance

Note: Means the dominance $Y<0.01$, *means not shown 
Table 3: Seasonal variation of diversity and evenness of zooplankton.

\begin{tabular}{|lllllll|}
\hline Season & \multicolumn{2}{l}{ Pielou's index $(d)$} & & \multicolumn{2}{l}{ Diversity index $\left(H^{\prime}\right)$} & \multicolumn{2}{l|}{ Evenness index $\left(J^{\prime}\right)$} \\
\cline { 2 - 7 } & Mean & Range & Mean & Range & Mean & Range \\
\hline Spring & 0.93 & $0.33-2.49$ & 0.62 & $0.00-2.35$ & 0.29 & $0.09-0.96$ \\
Summer & 1.28 & $0.62-2.23$ & 1.55 & $0.64-2.45$ & 0.80 & $0.28-0.97$ \\
Autumn & 2.03 & $0.69-3.05$ & 2.47 & $1.38-3.22$ & 0.90 & $0.79-0.99$ \\
Winter & 2.75 & $1.95-3.75$ & 2.66 & $2.00-3.28$ & 0.98 & $0.91-1.00$ \\
Annual Mean & 1.75 & $0.33-3.75$ & 1.83 & $0.00-3.28$ & 0.74 & $0.09-1.00$ \\
\hline
\end{tabular}

Table 4: Pearson correlation analysis between parameters of zooplankton and environmental factors.

\begin{tabular}{|c|c|c|c|c|c|c|c|c|}
\hline \multirow[t]{2}{*}{ Environment factors } & \multicolumn{2}{|c|}{ Number of species } & \multicolumn{2}{|c|}{ Abundance } & \multicolumn{2}{|c|}{ Biomass } & \multicolumn{2}{|c|}{ Diversity index } \\
\hline & $R$ & $P$ & $R$ & $P$ & $R$ & $P$ & $R$ & $P$ \\
\hline Temperature $\mathrm{T}$ & -0.040 & 0.724 & -0.144 & 0.203 & -0.577 & $0.000 * *$ & 0.257 & $0.021^{*}$ \\
\hline Salinity S & 0.468 & $0.000 * *$ & 0.363 & $0.000 * *$ & -0.074 & 0.515 & 0.503 & $0.000 * *$ \\
\hline $\mathrm{pH}$ & 0.456 & $0.000 * *$ & 0.625 & $0.000 * *$ & -0.210 & 0.062 & 0.728 & $0.000 * *$ \\
\hline Chemical Oxygen Demand COD & -0.272 & $0.015^{*}$ & -0.683 & $0.000 * *$ & 0.167 & 0.139 & -0.622 & $0.000 * *$ \\
\hline nitrate-nitrogen $\left(\mathrm{NO}_{3}\right)$ & -0.187 & 0.100 & -0.005 & 0.967 & 0.395 & $0.000 * *$ & -0.268 & $0.016^{*}$ \\
\hline labile phosphate $\left(\mathrm{PO}_{4}\right)$ & 0.035 & 0.756 & 0.205 & 0.068 & 0.435 & $0.000 * *$ & -0.094 & 0.409 \\
\hline
\end{tabular}

Note: *indicated $P$ level was 0.05 . **indicated $P$ level was 0.01

To further explore the correlations between zooplankton community structure and environmental factors, the canonical correlation analysis (CCA) between the abundance of 25 optimal zooplankton species and six water environmental factors was conducted, as showed in Table 5.

All the characteristic values of CCA sequencing explain $18.7 \%$ of the variation degree of zooplankton. The characteristic values of the first two sequencing axes were 0.662 and 0.529 , which together explain $15 \%$ of the change degree of the zooplankton community. The correlation coefficients between 25 species and 6 water environmental factor sequencing axes (the first axis and the second axis) were 0.956 and 0.886 , indicating a close correlation between the zooplankton and the water environmental factors. Thus, the results of CCA were credible. Furthermore, the Monte Carlo test showing that the first axis was significantly different from other axes $(\mathrm{P}<0.01)$ made the ranking results of CCA analysis more convincing.

The distinct clusters in species biplot of CCA analysis clearly revealed that the zooplankton spatio-temporal variation may be caused by different environmental variables. Furthermore, among all the environmental variables, the most important factors affecting the structure of the plankton community were $\mathrm{COD}, \mathrm{pH}$, and salinity, which is consistent with Pearson correlation analysis results shown in Table 4. In addition, CCA results divided 25 species of major zooplankton into three groups. The species of group I, including A. gibber, B. amoyensis, etc., were positively correlated with salinity, $\mathrm{pH}$, and labile phosphate, while negatively correlated with COD. On the contrary, group III (P. acirostris, C. larva, etc.) was positively correlated with COD but negatively correlated with salinity, $\mathrm{pH}$, and labile phosphate. Group II (L. penicilliger, C. furcatus, etc.) presented a positive correlation with temperature and a negative correlation with nutrient salts.

Zooplankton species number 1-8 is shown in Table 2. 9. Centropages furcatus 10. Acartia spinicauda 11. Oithona brevicornis 12. Schmackeria poplesia 13. Ccylla serrata 14. Paracalanus crassirostris 15. Nauplius larvae 16. Copepoda larva 17. Acartia pacifica 18. Canthocalanus pauper 19. Sinocalanus tenellus 20. Lucifer intermedius 21. Penaenus orientalis 22. Eriocheir sinensis 23. Eriocheir sinensis 24. Temora turbinata 25. Labidocera sinilobata

Table 5: Summary statistics for the axes of CCA performed on zooplankton.

\begin{tabular}{|c|c|c|c|c|}
\hline \multirow[t]{2}{*}{ items } & \multicolumn{4}{|c|}{ Sequencing axis } \\
\hline & 1 & 2 & 3 & 4 \\
\hline Characteristic value & 0.662 & 0.529 & 0.172 & 0.123 \\
\hline $\begin{array}{l}\text { Correlation of species and } \\
\text { environmental factors }\end{array}$ & 0.956 & 0.886 & 0.710 & 0.713 \\
\hline $\begin{array}{l}\text { Cumulative percentage of } \\
\text { species }\end{array}$ & 8.30 & 15.0 & 17.1 & 18.7 \\
\hline $\begin{array}{l}\text { Cumulative percentage of the } \\
\text { relationship between species } \\
\text { and environment }\end{array}$ & 41.1 & 74.0 & 84.7 & 92.3 \\
\hline Four sort the total eigenvalues & 7.96 & & & \\
\hline $\begin{array}{l}\text { Sum of all canonical eigen- } \\
\text { values }\end{array}$ & 1.61 & & & \\
\hline
\end{tabular}




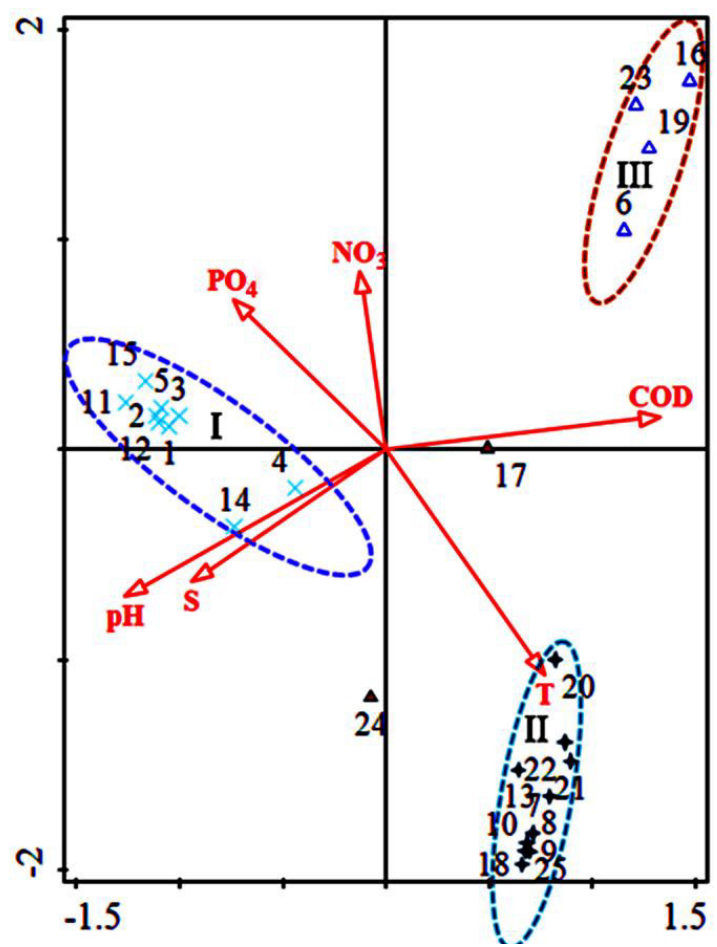

Fig. 4: Canonical correlation analysis between zooplankton species and environmental factors.

\section{DISCUSSION}

\section{Effects of Environmental Factors and Phytoplankton}

In the water, environmental conditions are complex and changing, affecting zooplankton species and communities. Temperature, salinity, and phytoplankton were the important factors influencing the distribution of zooplankton. During this study, a significant variation of water temperature exhibited a seasonal pattern: which increased after spring and reached a maximum in summer, decreased in autumn, and dropped to a minimum in winter. While the salinity showed higher values in winter and autumn than in spring and summer.

The concentration and rich nutrient content of phytoplankton were significantly correlated with the water quality characteristics in different seasons (Alagan et al. 2020, He et al. 2018, Lin et al. 2021, Shi et al. 2018, 2020, Wang et al. 2020). These environmental conditions affected the distribution of zooplankton and thus caused seasonal changes of the zooplankton community (Muthulakshmi et al. 2019, Thirunavukkarasu et al. 2020). Pearson correlation showed that all six environmental factors had affected zooplankton in different aspects, while $\mathrm{pH}$, salinity, and temperature were the most significant factors that influenced the 25 major zooplankton species.
The number of phytoplankton peaked in spring because of adequate nutrient salt, which had reached the level of red tide. With abundant food, low temperature, and low salinity, $N$. scintillans thrived and become the most dominant species $(\mathrm{Y}=0.86)$. S2 stood up with 31125 ind. $\mathrm{m}^{-3}$ among all the sample stations as shown in Fig. 3. Additionally, as a group III species (as discussed in 3.5), N. scintillans displayed a significant negative correlation with water temperature and salinity. A red tide of $N$. scintillans had occurred several times in the neritic areas of China, resulting in the death of mollusks such as scallops and oysters, and bringing huge economic losses to the fishery (Baliarsingh et al. 2016). In this survey, the massive propagation of $N$. scintillans was mainly distributed in near-shore and the Pearl River estuary area (with similar environmental conditions of previous $N$. scintillans-related red tides) (Mikaelyan et al. 2014). It indicates risks of occurrence of red tides caused by $N$. scintillans. In addition, low salinity zooplankton groups near the shore and estuaries such as Acartia pacifica and Sinocalanus laevidactylus were detected. In summer, the abundance of phytoplankton decreased significantly when water temperature increased and salinity decreased. Although the abundance of $N$. scintillans decreased, they remained the dominant species $(\mathrm{Y}=0.76) . N$. scintillans is mainly distributed in the pearl river estuary sea areas such as Station S3, S11, and S12, among which S11 presented the maximum abundance of 4650 ind. $\mathrm{m}^{-3}$. As salinity increased while the autumn temperature was still high, the density of phytoplankton as a food source decreased, and thus, replacement of dominant zooplankton species had taken place: $P$. acirostris and $L$. penicilliger became the dominant species, while the planktonic larvae began to multiply and became the absolute group. It can be seen from Fig. 4 that Nauplius larvae, belonging to group I, showed a positive correlation with salinity, while Penaenus orientalis and Eriocheir sinensis (in group II) were mainly positively correlated with temperature. The relationship between different species of planktonic larvae and environmental factors is quite different, which is consistent with previous research results (Fanjul et al. 2018). In winter, dominant species became $P$. parvus, A. gibber, B. amoyensis, and A. danae daphnia with both temperature and phytoplankton abundance decreasing, which were all negatively correlated with temperature.

\section{Other Effects}

It is important to note in particular that the direct effect of the nuclear power plants on the environmental changes was due to the increase in the temperature for the temperature drainage, which became a major factor affecting the marine ecological environment (Alibek 2016, Jiang \& Wang et al. 2020, Muthulakshmi et al. 2019). In this study, the differ- 
ences in the abundance distribution of zooplankton between the four voyage outlets and the neighboring stations were compared. As a result, zooplankton abundance near the outlet was not much different from that at the adjacent stations in spring; What mattered was the distance from shore: zooplankton abundance was higher at near shore stations than that at the stations in the open sea, indicating significant influence from tides. In summer, zooplankton abundance around the outlet and the south sea area is lower than that in the North Sea area, which indicates that the estuary runoff may have a great influence on the distribution of zooplankton. However, zooplankton abundance around the outlet is lower than those found at non-outlet stations in autumn, which is more likely related to temperature drainage from the nuclear power plant. The situation in winter is more complex with zooplankton distributed quite randomly. In conclusion, temperature drainage seems did affect zooplankton distribution in autumn.

\section{CONCLUSION}

In the seawater near Taishan Nuclear Power Station, a total of 48 species of zooplankton taxa belonging to 11 taxonomic groups were identified. At the taxonomic level, copepods covered the vast majority of zooplankton and they were mainly composed of low salinity groups near the shore, which is typical of subtropical flora. The differences in zooplankton density, biomass, and diversity indices were significant in different seasons. The results indicate that the abundance and biomass in spring were significantly higher than those in other seasons. However, the zooplankton diversity index was the lowest in spring and showed an upward trend till winter. According to Pearson correlation analysis and canonical correspondence analysis, $\mathrm{pH}$, salinity, and temperature were the principal factors affecting the distribution of zooplankton. By comparing the results among the study stations and between different seasons, it seems that the zooplankton community in the survey area was mainly determined by different seasons, estuary runoff, and tide. This study will be helpful in the further understanding of the threat of the Taishan Nuclear Power Station on the marine life and the coastal environment, and in providing scientific guidance for the protection of the ecological environment of surrounding seas.

\section{ACKNOWLEDGEMENT}

This paper was granted by State Key Laboratory of Organic Geochemistry, GIGCAS (No. SKLOG202011 and No. SKLOG202007), the Jiangxi Province Natural Science Foundation of China (No.20202BAB213021), the Guangdong Province Natural Science Foundation of China (No.
2017A030313329), and the National Natural Science Foundation of China (No. 51409287).

\section{REFERENCES}

Alibek, I. 2016. Mathematical modeling of the discharged heat water effect on the aquatic environment from thermal power plant under various operational capacities. Appl. Math. Model., 40(2): 1082-1096.

Alagan, M., Natesan, U., Ferrer, V.A. and Venugopalan, V.P. 2020. Effects of environmental variables on phytoplankton in the coastal waters of Kalpakkam with special emphasis on thermal discharge from a power plant, southeast coast of India. 6th International Scientific Conference Geobalcanica, 12-13May 2020, Ohrid, North Macedonia, Geobalcanica, Macedonia, pp. 31-45

Asgari, M. and Steiner, C.F. 2017. Interactive effects of productivity and predation on zooplankton diversity. Oikos, 130(8): 45-57.

Baliarsingh, S.K., Lotliker, A.A., Trainer, V.L., Wells, M.L., Parida, C., Sahu, B.K., Srichandan, S., Sahoo, S., Sahu, K.C. and Kumar, T.S. 2016. Environmental dynamics of red Noctiluca scintillans bloom in tropical coastal waters. Marine Pollution Bulletin, 111(1-2): 277-286.

Batchelder, H.P., Daly, K.L. and Davis, C.S. 2013. Climate impacts on zooplankton population dynamics in coastal marine ecosystems. Oceanography, 26: 34-51.

Buesseler, K., Dai, M.H., Aoyama, M., Benitez-Nelson, C. and Morris, P.J. 2016. Fukushima Daiichi-derived radionuclides in the ocean: Transport, fate, and impacts. Annu. Rev. Mar. Sci., 9(1): 1.1-1.31.

Chen, X., Ji P., Wu Y.H., Zhao, Y.J. and Zeng, L. 2017. Coupling simulation of overland flooding and underground network drainage in a coastal nuclear power plant. Nucl. Eng. Des., 325: 129-134.

Ding, X.W., Tian, W., Zhai, A.F., Kang, B. and Zhu, Q. 2019. Research on water intake, usage, and drainage impact demonstration for coastal nuclear power plants. IOP Conf. Ser - Earth Environ. Sci., 36: 515-539.

Fanjul A., Iriarte A., Villate F., Uriarte, I., Atkinson, A. and Cook, K. 2018. Zooplankton seasonality across a latitudinal gradient in the Northeast Atlantic Shelves Province. Continental Shelf Research: A Companion Journal to Deep-Sea Research and Progress in Oceanography.

Goncalves, A.M.M., Azeiteiro U.M., Pardal M.A. and Troch, M.D. 2012. Fatty acid profiling reveals seasonal and spatial shifts in the zooplankton diet in a temperate estuary. Estuar. Coast. Shelf Sci., 109: 70-80.

He, R., Jiang, R., Zhu, X.P., Guo, W., Li, Z.X. and Xu, N. 2018. Seasonal variation of phytoplankton and its relationship with environmental factors in sea waters near Taishan. Chinese Journal of Ecology.

Jiang, S. and Hou, J. 2015. The impact analysis for the marine environment which caused by the thermal discharge of the power plant. International Forum on Energy, Environ, Sci. Mater.,6: 35-51

Jiang, R. and Wang, Y.S. 2020. Modeling the ecosystem response of the semi-closed Daya bay to the thermal discharge from two nearby nuclear power plants. Ecotoxicology, 29(2):11-23.

Lin, J., Zou, X. and Huang, F. 2021. Quantitative analysis of the factors influencing the dispersion of thermal pollution caused by coastal power plants. Water Res., 188: 116558.

Maja, M.K., Lidia, D.G. and Agata, W. 2018. Influence of environmental factors on the population dynamics of key zooplankton species in the Gulf of Gdańsk (Southern Baltic Sea). Oceanologia, S0078323418300691.

Mikaelyan, A.S., Malej, A., Shiganova, T.A., Turk, V., Sivkovitch, A.E., Musaeva, E.I., Kogovsek, T. and Lukasheva, T.A. 2014. Populations of the red tide forming dinoflagellate Noctiluca scintillans (Macartney): A comparison between the Black Sea and the northern Adriatic Sea. Harmful Algae, 33: 29-40.

Muthulakshmi, A.L., Natesan, U., Ferrer, V.A., Deepthi, K. and Narasimhan, S.V. 2019. Impact assessment of nuclear power plant discharge on zooplankton abundance and distribution in coastal waters of Kalpakkam, India. Ecol. Proces., 8(1): 22. 
Pielou, E.C. 1969. An Introduction to Mathematical Ecology, WileyInterscience, New York, pp. 1-28.

Richardson, J., Feuchtmayr, H., Miller, C., Hunter, P.D., Maberly, S.C. and Carvalho, L. 2019. The response of cyanobacteria and phytoplankton abundance to warming, extreme rainfall events, and nutrient enrichment. Glob. Change Biol., 25(1).

Shannon, C.E. and Weaver, W. 1949. The Mathematical Theory of Communication, University of Illinois Press, Urbana IL, pp. 1-125.

Shi, Y.Q., Niu, M.X., Zuo, T., Wang, J. and Pakhomov, E.A. 2020. Interannual and seasonal variations in zooplankton community structure in the Yellow Sea with the possible influence of climatic variability. Prog. Oceanogr., 185: 102349.

Shi, Y.Q., Zuo, T., Yuan, W., Sun, J.Q. and Wang, J. 2018. Spatial variation in zooplankton communities in relation to key environmental factors in the Yellow Sea and the East China Sea during winter. Cont. Shelf Res., 170: 33-41.

Sonia, R.R., Ricardo, G.G., Carlos, C. and Acua, J.L. 2019. Seasonal and vertical dynamics in the trophic structure of a temperate zooplankton assemblage. Limnol. Oceanogr., 64: 434-451.
Steinberg, D.K. and Landry, M.R. 2017. Zooplankton and the ocean carbon cycle. Annu. Rev. Mar. Sci., 9: 413-444.

Thirunavukkarasu, S., Vasanthi, R., Karunasagaran, G. and Munuswamy, N. 2020. Coastal water quality impact on community structure and genotoxicity of marine zooplankton. Reg. Stud. Marine Sci., 39: 18-31

Walkusz, W., Kwasniewski, S., Falk-Petersen, S., Hop, H. and Weslawski, J.M. 2009. Seasonal and spatial changes in the zooplankton community of Kongsfjorden, Svalbard. Polar Res., 28(2): 1-17.

Wang, M.L., Wang, Y.T., Chen, H., Sun, F.L. and Wang, Y.S. 2020. Phytoplankton community, structure, and succession delineated by partial least square regression in Daya Bay. The South China Sea, 29: 751-761.

Wu, J.X., Yan, B.L., Feng, Z.H., Li, Y. and Shen, X. 2011. Zooplankton ecology near the Tianwan Nuclear Power Station. Acta Ecol. Sin., 31(22): 6902-6911.

Zervoudaki, S., Nielsen, T.G. and Carstensen, J. 2009. Seasonal succession and composition of the zooplankton community along a eutrophication and salinity gradient exemplified, by Danish waters. J. Plankton Res., 31(12): 1475-1492. 